\title{
Marfan Sendromlu Gebede Anestezi Yönetimi
}

\author{
Anesthesia Management of a Patient with Pregnant Marfan Syndrome
}

\author{
Gülçin AYDIN ${ }^{1}$, Işın GENÇAY ${ }^{1}$, Ferda YAMAN ${ }^{1}$, Selim ÇOLAK ${ }^{1}$, \\ Cemile DAYANGAN SAYAN² ${ }^{2}$, Gülcan BAKKAL ${ }^{1}$, Ünase BÜYÜKKOÇAK ${ }^{1}$
}

${ }^{1}$ Kırlkkale Üniversitesi Tip Fakültesi, Anesteziyoloji ve Reanimasyon Anabilim Dall, KIRIKKALE

${ }^{2}$ Kırıkkale Üniversitesi Tıp Fakültesi, Kadın Hastalıkları ve Doğum A.D., KIRIKKALE

\begin{abstract}
ÖZET
Marfan Sendromu (MS) 1/5000 oranında otozomal dominant geçiş gösteren bir bağ doku hastalığıdır. Fibrillin-1 (FBN1) geninin $15 \mathrm{q} 21$ kromozomunda mutasyon vardır. İskelet sistemi anormallikleri, lens dislokasyonu, dural ektazi ve aort dilatasyonu ile karakterizedir. Hastaların \%80'ninde kardiyovasküler sistemde birtakım değişiklikler mevcut olup bunlar; aort dilatasyonu, aort yetmezliği, mitral-triküspit valv prolapsusu ve regürjitasyonudur. Majör ölüm nedenleri arasında aortik anevrizma rüptürü ve diseksiyonu yer alır. Gebelikteki fizyolojik değişiklikler aort diseksiyonu patogenezi ve progresyonuna katkıda bulunmaktadır.

Gebelikte artmış aort kompliyansı ve bunun sonucunda aort dilatasyonu sözkonusudur. Gebelik ve doğum MS'lu hastalarda yaşamı tehdit eden diseksiyonlara yol açar; özellikle de aort çap1 $40 \mathrm{~mm}$ ' den geniş ise. MS'lu gebelerde lumbal spinal deformiteler ve yaygın artrodezisler, epidural ve spinal anestezi başarısızlı̆̆ını artırır. Benzer şekilde dural ektaziler dural delinme riskinin artmasina neden olur. $\mathrm{Bu}$ olgu sunumuyla MS'lu gebe kadinda elektif sezaryen operasyonunda genel anestezi uygulamamızı sunmayı amaçladık.
\end{abstract}

Anahtar Kelimeler: Marfan Sendromu, diseksiyon, genel anestezi

\section{GíRiş}

Marfan Sendromu (MS), iskelet sistemi anormallikleri (pektus deformiteleri, skolyozis), oküler lens dislokasyonu, duktal ektazi, progresif aort dilatasyonu ve aort diseksiyon riski ile karakterize bir bağdoku hastalığıdır $(1,2)$. MS otozomal dominant geçiş gösteren, ekstraselüler matriksteki geniş bir glikoprotein olan FBN-1geninin 15q21

kromozomundaki mutasyonun neden olduğu hastalık

olup 1/5000 oranında görülme insidansına sahiptir (36). MFS'lu kadınlarda gebelikte meydana gelen fizyolojik değişiklikler, artmış aortik dilatasyon ve aort diseksiyonu riskine neden olur (7,8). Gebelik sırasındaki aortik komplikasyonların riski asendan aortanın boyutları ile ilişkilidir. Aortik çap $>40 \mathrm{~mm}$ üzerinde olan kadınlarda gebelik rölatif 
kontrendikasyon olup aortik çapı $\geq 45 \mathrm{~mm}$ 'nin üzerinde gebeliğe başlangıç diseksiyon açısından yüksek risk taşır (2). Aort komplikasyonları için artmış risk; gebelikteki hormonal ve hemodinamik değişikliklerle ilişkilidir. Gebelik hipervolemik ve hiperdinamik bir kardiyovasküler duruma yol açar. Kalp hızı ve stroke volümdeki artış ile beraber gestasyonun 32. haftalarında kardiyak output \%30-50 'nin üzerinde $\operatorname{artar}(9,10)$. $\beta 2$ adrenerjik reseptör antagonizması sonucunda uterin kontraksiyonlara neden olmasına rağmen $\beta$-blokörler arteryal duvar stresini azalttığ 1 için standart tedavide kullanılır. MS'lu hastalarda verilen Landiolol kısa etkili selektif Beta-1 adrenerjik reseptör antagonisti olup sezaryen operasyonlarındaki hemodinamik değişiklikleri stabilleyerek diseksiyon gelişimini önler (11). Dural ektazi MS'lu hastaların \%60-90'1nda mevcuttur (12,13). Nöroaksiyel anestezi hem hemodinamik dalgalanmaları (sempatik blok nedeniyle hipotansiyon ve bradikardi) dengede tutmak açısından sıkıntılı olup, hem de dural kesedeki balonlaşmanın bos hacmini artırmasından dolayı anatomiyi bozarak bu işlemi zorlaştırmaktadır. Bu durum ise en iyi anestezi tekniği konusunda anestezisti düşündürmektedir $(12,14)$. Biz bu olgu sunumuyla MS'lu gebedeki elektif sezaryen vakasında yapılan genel anestezi tekniğini literatürler eşliğinde tartışarak sunmayı amaçladık.

\section{OLGU}

23 yaşında, $58 \mathrm{~kg}$ ağırlığında ve $175 \mathrm{~cm}$ boyundaki 38 haftalık gebeye Kadın Doğum Bölümü tarafindan elektif sezaryen operasyonu planlandı. Hastanın hikâyesinde ilk gebeliği olduğu, daha önce anestezi almadığı, supraventriküler taşikardi (SVT) tanısı ile dış merkezde takiplerinin olduğu, 2008 y1lında Radyofrekans Ablasyon (RFA) yapıldığı, 2010 yılında ise Koroner Anjiografi (KAG) yapıldığı ve normal olduğu öğrenilmiştir. Gebelikteki takiplerinde Kadın Doğum ve Kardiyoloji bölümü tarafindan 28 . haftasında MS tanısı almıştır. Bu haftadan itibaren, $\beta$ blokör (Beloc $25 \mathrm{mg}$ tablet $1 \mathrm{x}$ ) t) tedaviye başlanan hastanın preoperatif ekokardiyografisinde; aort kapağ triküspitli, mitral valv prolapsusu, 1. derece mitral yetmezliği, mitral kapakta miksomatöz değişiklikleri mevcuttu. Asendan aorta normal sinırlarda, sinüs valsalva $3 \mathrm{~cm}$ idi. Fizik muayenesinde alt ve üst ekstremite boyları normalden uzun, eklem hipermobilitesi özellikle de el bileklerinde mevcut olup el bilekleri 90 derece extansiyona gelebilmekteydi (Resim 1). Asimetrik pectus deformitesi vardı; sol sternum ve alttaki kosta kartilajlarında arkaya doğru çökme mevcuttu. Sol sternumun alt yarısı etkilenmişti (Resim 2).

Mallampatisi grade III olan hastanın boyun extansiyon ve fleksiyonunda kısıtlılık yoktu. 8 saat süren açlığı takiben premedikasyon uygulanmadan operasyon odasına alınan hastaya kalp hızı, periferik oksijen satürasyonu $\left(\mathrm{SpO}_{2}\right)$ monitorizasyonu yapıldı. Her iki el üzerinden 18 ve 20 gauge intraket ile intravenöz (iv) damar yolları açılarak $8 \mathrm{ml} / \mathrm{kg}$ Ringer laktat solüsyonu 20 dakikada infüze edildi. Sol radial arter kateterizasyonu açılarak arteryal kan basıncı monitörizasyonu uyguland. Preoperatif kan basıncı: 130/75, kalp hızı: 83/dk ve $\mathrm{SpO}_{2}: \% 98$ olarak kaydedildi. İntraoperatif ve postoperatif hemodinamik instabilitenin önlenmesi açısından hastaya 0.02-0.08 $\mu \mathrm{g} / \mathrm{kg} / \mathrm{h}$ ' den esmolol (Brevibloc Premiks $10 \mathrm{mg} / \mathrm{mL}$, Eczacıbaşı-Baxter, İstanbul) infüzyonu başlandı.

Zor havayolu için gerekli bütün ekipmanlar ve fiberoptik laringoskopi hazırlığı yapıldı. Bütün cerrahi hazırlıkların tamamlanmasından sonra Propofol $(2 \mathrm{mg} / \mathrm{kg})$ iv, Roküronyum bromür $(1 \mathrm{mg} / \mathrm{kg})$ iv indüksiyon yapılarak krikoid bası ile 90. saniyede 2 . denemede stile ile entübe edildi. Cerrahi başladıktan 3,5 dk sonra APGAR skalas1 1. dk'da 9, 5. dk'da 10 olan kız bebek doğurtuldu. Bebek çıktıktan sonra, Fentanil (2mcg/kg) iv yapılarak, anestezi idamesi \%45$550_{2}$-hava ve \% 2 Sevoflurane ile sağland. 


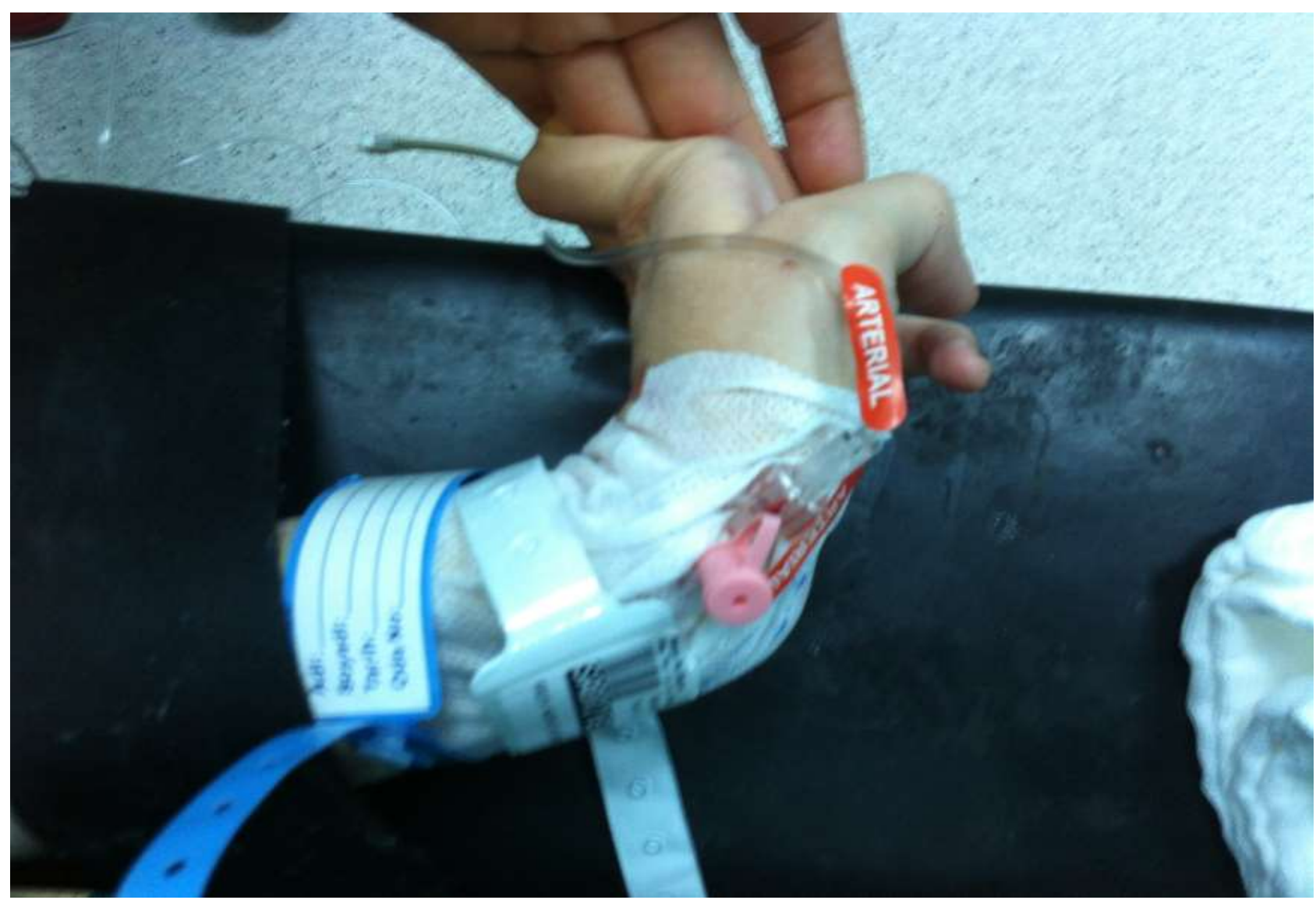

Resim 1: El bileği laksitesi

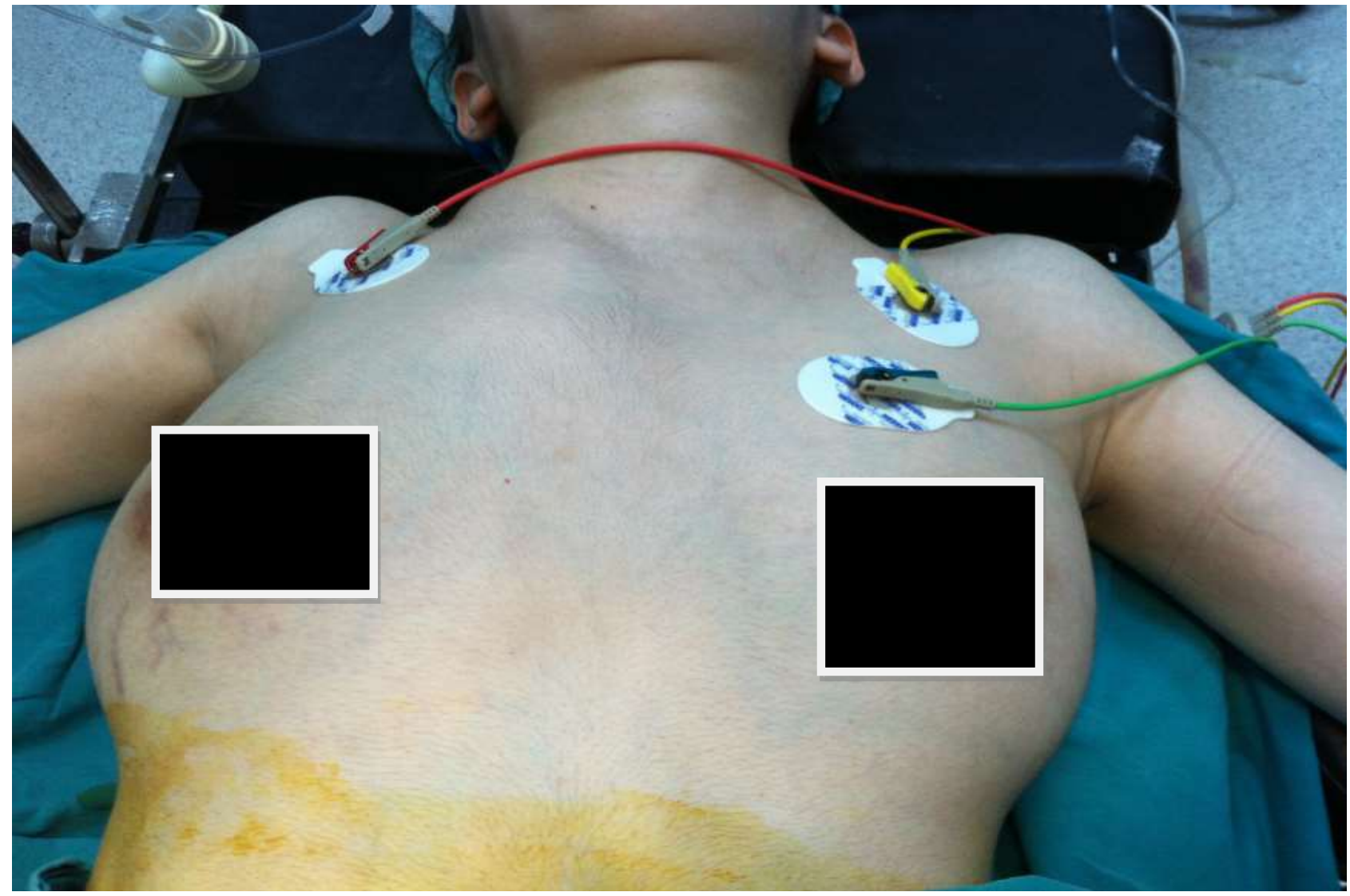

Resim 2: Pectus Karinatum deformitesi 
İntraoperatif arteriyel basınçları $110 / 70 \quad \mathrm{mmHg}$ düzeyinde tutalacak şekilde Esmolol infüzyonu ile özellikle entübasyon ve ekstübasyondaki hemodinamik dalgalanmalar önlendi. 35 dakika süren operasyon boyunca $70 \mathrm{mg}$ iv rokuronyum bromür yapılan hastaya operasyon bitiminde iv $4 \mathrm{mg} / \mathrm{kg}$ sugammadeks yapılarak 180 sn sonra ekstübe edildi. Ekstübasyon sonrası hasta başını 5 saniyeden fazla yukarıda tutabiliyor, spontan gözlerini açabiliyor ve kooperasyon kurabiliyordu. Hasta operasyonun ardından sorunsuz bir şekilde servise alındı.

\section{TARTIŞMA}

1896 y1lında, Antoine-Bernard, Paris Tıp Cemiyeti yıllık toplantısında Marfan adıyla yeni bir bağ dokusu hastalığ1 sunmuştur. Uzun ince ekstremiteleri olan 5 yaşında bir kız çocuğunun klinik hikâyesini tanımlamıştır. Bu tanımlamadan sonra lens ektopisi ve aort dilatasyonu da eklenerek bu klinik 1914 yılında MS olarak adlandırılmıştır. 1931 yılında ise otozomal dominant olarak kalitsal geçiş gösterdiği bulunmuştur. Bentall ve De Bono 1968 y1lında aort dilatasyonunun cerrahi tedavisindeki aort replasmanı için "Bentall" prosedürünü geliştirmişlerdir. MS, diğer bağ doku hastalıkları ile klinik ve fenotipik açıdan benzerlik gösterebildiğinden bu hastaların teşhisi Ghent Kriterlerine (Tablo 1) göre yapılmalıdır; bu da çoklu organ sistemleri açısından kapsamlı bir klinik değerlendirme gerektirir $(15,20)$. Ghent Kriterlerine göre MS tanısı için sistemlerin en az ikisinde majör bulgular olmalı ve üçüncü bir sistem de tutulmuş olmalıdır (20). Bizim hastamızda toraks deformitesi, hipermobil ve hiperlaksite eklemler, karında strialar, mitral valv prolapsusu, 1. derece mitral yetmezliği ve mitral kapakta miksomatöz değişiklikleri mevcuttu. FBN-1 mutasyonu da genetik araştırmada pozitif olarak bulunmuştu.
Gebelikteki fizyolojik değişiklikler aort diseksiyonu patogenezi ve progresyonuna katkıda bulunmaktadır. Bu değişikliklerin en önemlileri artmış kan hacmi, kalp hızı ve kan basıncıdır. Gebedeki artmış östrojen de aort bağ doku gücünün azalmasına etkili faktörler arasındadır. Özellikle artan çapa sahip çıkan aort, aort veya orta mitral kapak lezyonları olanlarda gebelik tavsiye edilmez. Öte yandan, aort çapı 40-45 mm'den az olanlarda gebelik güvenlidir. Normal tansiyonlara sahip MS'lu gebelerin antihipertansif ilaç alımı her ne kadar tartışmalı ise de yüksek riskli hastalarda özellikle üçüncü trimestride ilaç kullanımı makul olabilir [11]. $\beta$-bloker tedavi uterus kontraksiyonlarına sekonder doğum ağrısını indükleyebilir fakat bu tedavi yokluğunda aort dilatasyonunun progresif kötüleşmesi meydana gelir. Gebeliğin bağ dokuya etkilerinden ve artmış kardiyak output ilişkili aort duvar basısından dolayı aort dilatasyonu sürecini hızlandırır (16). Bizim hastamızın aort kapağı triküspitli, mitral valv prolapsusu, 1. derece mitral yetmezliği ve mitral kapakta miksomatöz değişiklikleri mevcuttu. Asendan aorta normal sınırlardaydı ve sinüs valsalva $3 \mathrm{~cm}$ idi. 28. haftasında başlanan $\beta$-bloker tedavi ile tansiyonları normal sınırlarda seyreden hasta operasyon sabahına kadar ilacını almıştı.

MS'lu hastalarda anestezi ve analjezi seçimi açısından ideal bir teknik tanımlanmamıştır. Lumbal spinal deformiteler ve artrodezler başarılı epidural kateter ve spinal iğne yerleşimlerini zorlaştırabilir. Dural ektazi (dural kanalın genişlemesi) ise MS'lu hastaların \%6090'nında mevcuttur $(13,17)$. Dural ektazinin olması, doğum analjezisi ve başarısız spinal blok sonrası takılan epidural kateter sırasında artmış dural delinme riski ile ilişkilidir (16). Dural ektazi MS'lu hastalarda \%41 oranında da asemptomatik bulunmuştur (18). Ektazik bölgenin radyolojik olarak konformasyonu anestezi yönetiminin planlanmasında oldukça önemlidir (12). Bizim hastamızın onam vermemesi sebebiyle magnetik rezonans görüntüleme yapılamadı. 
Tablo 1: Ghent Kriterleri

\begin{tabular}{|c|c|c|}
\hline & MAJÖR KRİTERLER & MINÖR KRİTERLER \\
\hline \multirow[t]{9}{*}{ İSKELET SİSTEMİ } & Pektus karinatum & Pektus ekskavatum (orta) \\
\hline & Pektus ekskavatum (cerrahi) & Hipermobil eklemler \\
\hline & Anormal kol mesafesi / uzunluk & Çok sayıda diş ile yüksek damak \\
\hline & oran1 & Tipik yüz görünümü \\
\hline & Bilek başparmak işareti & \\
\hline & Artmış skolyoz ve spondilolistezis & \\
\hline & Azalmış dirsek ekstansiyonu & \\
\hline & Medial malleolusun medial çıkığı & \\
\hline & Asetabular protrüzyon & \\
\hline \multirow[t]{2}{*}{ OKÜLER SİSTEM } & - & Artmış globe uzunluğu \\
\hline & - & İris ve siliyer adale hipoplazisi \\
\hline \multirow{5}{*}{$\begin{array}{l}\text { KARDİYOVASKÜLER } \\
\text { SİSTEM }\end{array}$} & \multirow{5}{*}{$\begin{array}{l}\text { Asendan aort dilatasyonu } \pm \mathrm{AY}^{*} \\
\text { Valsalva sinüs tutulumu } \\
\text { Stanford Tip A aort diseksiyonu }\end{array}$} & $\mathrm{MKP}^{£} \pm \mathrm{MY}^{€}$ \\
\hline & & Pulmoner arterin dilatasyonu \pm \\
\hline & & pulmoner darlık $(<40$ yaş $)$ \\
\hline & & Kalsifiye mitral annulus ( $<40$ yaş) \\
\hline & & $\begin{array}{l}\text { Abdominal veya desendan aortada } \\
\text { anevrizma/diseksiyon }(<50 \text { yaş })\end{array}$ \\
\hline PULMONER SISTEM & - & Spontan pnömotoraks \\
\hline \multirow[t]{2}{*}{ DERİ } & - & Apikal blebler \\
\hline & - & Stria (gebelik \pm ) \\
\hline DURA & Dural ektazi & Tekrarlayan ve insizyonel herniasyon \\
\hline \multirow[t]{2}{*}{ GENETİK } & Fibrillin-1 mutasyonu & - \\
\hline & $\begin{array}{l}\text { DNA haplotipinin kalıtımı ailesel } \\
\text { MS ile ilişkilidir }\end{array}$ & \\
\hline
\end{tabular}

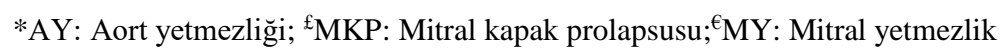

Genel anestezi sırasındaki laringoskopi ve cerrahiye hemodinamik yanıt aort kökü için önemli bir stres faktörüdür. $\mathrm{Bu}$ nedenle hastalar operasyon gününe kadar $\beta$-blokör tedavisini almalıdırlar (11). Bizim hastamız $\beta$-blokör tedavisini operasyon sabahına kadar almıştır. Genel anestezinin bir avantajı da akut diseksiyon ve acil kardiak cerrahi gerekmesi durumunda havayolunun korunabilmesidir. Diğer bir düşünce ise inhalasyon ajanlarının potansiyel olarak kardiak ejeksiyonu azaltması ve diseksiyon riskini azaltmasıdır. Genel anestezinin dezavantajı ise uygun farmakoloji ile önlenemeyen hayatı tehdit eden entübasyona hipertansif yanıttır. Başarısız entübasyon ve aspirasyon riski de diğer dezavantajlardandır. Önceden dikkatli bir havayolu muayenesi ve krikoid bas1 ile bu durum en aza indirilebilir (19). Bizim hastamızda genel anestezinin yaratacağı hemodinamik değişikliklerde indüksiyon öncesinde arter monitorizasyonu için radial arter kanülasyonu yapılmıştır ve kan basıncı-kalp hızındaki değişiklikleri minimize etmek amaciyla preoperatif esmolol infüzyonu başlanmıştır. 
Sonuç olarak MS'lu gebelerde fertilizasyonla beraber sık ve yakın takip, erken $\beta$-blokör tedaviye başlanması ve seri ekokardiyografik değerlendirme ile gebelik boyunca hemodinamik istikrarın sağlanması mümkündür. Multidispliner bir yaklaşım ile kar-zarar oranı ve hastanın tıbbi durumu göz önünde bulundurularak en az hemodinamik etkilenmenin olacağı doğum şekli belirlenmelidir. Hedef, en uygun analjezi ve anestezi seçimi ile aort kökü stresinden ve hemodinamik dengesizlikten kaçınma olmalıdır.

\section{KAYNAKLAR}

1 Keane MG, Pyeritz RE. Medical management of Marfan syndrome. Circulation. 2008; 117(21): 2802-13.

2 Cox DA, Ginde S, Kuhlmann RS, Earing MG. Management of the pregnant woman with Marfan syndrome complicated by ascending aorta dilation. Archives of Gynecology and Obstetrics 2014; 290(4): 797-802.

3 Loeys BL, Dietz HC, Braverman AC, Callewaert BL, De Backer J, Devereux RB, Hilhorst-Hofstee Y, Jondeau G, Faivre L, Milewicz DM. The revised Ghent nosology for the Marfan syndrome. Journal ofMedical Genetics. 2010; 47(7): 476-85.

4 Dietz HC, Cutting CR, Pyeritz RE, Maslen CL, Sakai LY, Corson GM, Puffenberger EG, Hamosh A, Nanthakumar EJ, Curristin SM. Marfan syndrome caused by a recurrent de novo missense mutation in the fibrillin gene. Nature. 1991; 352(6333): 337-9.

5 Kielty CM, Shuttleworth CA. Fibrillin-containing microfibrils: structure and function in health and disease. The İnternational Journal of Biochemistry and Cell Biology. 1995; 27(8): 747-60.

6 Hollister DW, Godfrey M, Sakai LY, Pyeritz RE. Immunohistologic abnormalities of the microfibrillar-fiber system in the Marfan syndrome. New England Journal of Medicine. 1990; 323(3): 152-9.

7 Rossiter JP, Repke JT, Morales AJ, Murphy EA, Pyeritz RE. A prospective longitudinal evaluation of pregnancy in the Marfan syndrome. American Journal of Obstetrics and Gynecology. 1995; 173(5): 1599-606.

8 Pacini L, Digne F, Boumendil A, Muti C, Detaint D, Boileau C, Jondeau G. Maternal complication of pregnancy in Marfan syndrome. International Journal of Cardiology. 2009; 136(2): 156-61.

9 Earing MG, Webb GD. Congenital heart disease and pregnancy: maternal and fetal risks. Clinics in Perinatology. 2005; 32(4): 913-9.

10 Barrett JM, Van Hooydonk JE, Boehm FH. Pregnancy-related rupture of arterial aneurysms. Obstetrical and Gynecological Survey. 1982; 37(9): 557-66.

11 Saeki N, Taguchi S, Kawamoto M. Successful management of a patient with Marfan syndrome complicated with acute aortic dissection using landiolol during Cesarean section. Journal of Anesth. 2010; 24(2): 277-9.

12 McNeilly G, Nicholl A, Broadway J, Rao S. Dural ectasia in Marfan's syndrome: magnetic resonance imaging appearances and anaesthetic experience of three deliveries. International Journal of Obstetric Anesth. 2013; 22(4): 337-9.

13 Buser RT, Mordecai MM, Brull SJ. Combined spinal-epidural analgesia for labor in a patient with Marfan's syndrome. Int J Obstet Anesth. 2007; 16(3): 274-6.

14 Kuczkowski KM. Labor Analgesia for the Parturient With an Uncommon Disorder: A Common Dilemma in the Delivery Suite. 
Obstetrical and Gynecological Survey. 2003; 58(12): 800-3.

15 Castellano JM, Silvay G, Castillo JG. Marfan Syndrome: Clinical, Surgical, and Anesthetic Considerations. In: Seminars in cardiothoracic and vascular anesth: 2013; SAGE Publications. 2013; 1089253213513842.

16 Allyn J, Guglielminotti J, Omnes S, Guezouli L, Egan M, Jondeau G, Longrois D, Montravers P. Marfan's syndrome during pregnancy: anesthetic management of delivery in 16 consecutive patients. Anesth and Analg. 2013; 116(2): 392-8.

17 Fattori R, ANienaber C, Descovich B, Ambrosetto P, Reggiani LB, Pepe G, Kaufmann U, Negrini E, von Kodolitsch Y, Gensini GF. Importance of dural ectasia in phenotypic assessment of $M$ arfan's syndrome. The Lancet. 1999; 354(9182): 910-3.

18 Ahn NU, Sponseller PD, Ahn UM, Nallamshetty L, Kuszyk BS, Zinreich SJ. Dural ectasia is associated with back pain in Marfan syndrome. Spine. 2000; 25(12): 1562-8.

19 Singh SI, Brooks C, Dobkowski W. General anesthesia using remifentanil for Cesarean delivery in a parturient with Marfan's syndrome. Canadian Journal of Anaesth. 2008; 55(8): 526-31.

20 Dean JC. Management of Marfan syndrome. Heart. 2002; 88(1): 97-103. 